\title{
KARAKTERISASI KOEFISIEN ABSORBSI BUNYI DAN IMPEDANSI AKUSTIK DARI LIMBAH SERAT KAYU MERANTI MERAH (SHOREA PINANGA) DENGAN MENGGUNAKAN METODE TABUNG
}

\author{
Sonya Yuliantika*, Elvaswer Elvaswer \\ Laboratorium Fisika Material, Jurusan Fisika FMIPA Universitas Andalas \\ *Korespondensi ke: sonyayuliantika@gmail.com \\ ( Diterima:29 Januari 2018; Direvisi: 15 Februari 2018; Diterbitkan: 01 Maret 2018)
}

\begin{abstract}
ABSTRAK
Penelitian menentukan koefisien absorbsi bunyi dan impedansi akustik dari serat kayu Meranti Merah telah dilakukan. Sampel panel akustik dibuat dari serat kayu Meranti Merah dengan variasi lebar lembaran serat dan panjang serat. Lebar lembaran seratnya adalah antara $0,5 \mathrm{~cm}, 1 \mathrm{~cm}, 1,5$ $\mathrm{cm}$ dan $2 \mathrm{~cm}$ dan panjang seratnya adalah $1 \mathrm{~cm}, 2 \mathrm{~cm}, 3 \mathrm{~cm}$ dan $4 \mathrm{~cm}$. Pengukuran menggunakan frekuensi dari $500 \mathrm{~Hz}, 1000 \mathrm{~Hz}, 1500 \mathrm{~Hz}, 2000 \mathrm{~Hz}$ dan $2500 \mathrm{~Hz}$. Nilai koefisien absorbsi bunyi tertinggi adalah $0,95 \pm 0,05$ untuk frekuensi $1000 \mathrm{~Hz}$ dengan lebar dan panjang serat $0,5 \mathrm{~cm}$ dan 2 $\mathrm{cm}$. Nilai impedansi akustik untuk koefisien absorbsi bunyi ini adalah 1,83 dyne.s $/ \mathrm{cm}^{3}$. Dengan demikian berdasarkan koefisien absorbsi bunyi maka serat kayu Meranti Merah potensial untuk digunakan sebagai bahan penyerap bunyi. Nilai impedansi akustik secara umum memiliki hubungan yang kuat dengan koefisien absorbsi bunyi pada frekuensi $1000 \mathrm{~Hz}$ dengan $\mathrm{R}^{2}=0,948$ Kata kunci : koefisien absorbsi bunyi, impedansi akustik, serat kayu Meranti Merah
\end{abstract}

\section{ABSTRACT}

This research is aimed at determining sound absorption coefficient and acoustic impedance of red Meranti wood fibers. The acoustic panel sampels were prepared from red Meranti wood fibers with different width or length. The width was varied from $0,5 \mathrm{~cm}$ to $2 \mathrm{~cm}$ with the interval of 0,5 $\mathrm{cm}$ and the length was varied from $1 \mathrm{~cm}$ to $4 \mathrm{~cm}$ with the interval of $1 \mathrm{~cm}$. The measurements were carried out at the frequencies of $500 \mathrm{~Hz}, 1000 \mathrm{~Hz}, 1500 \mathrm{~Hz}, 2000 \mathrm{~Hz}$ and $2500 \mathrm{~Hz}$. The highest sound coefficient absorption was 0,95 $\pm 0,05$ at the frequency of $1000 \mathrm{~Hz}$ for sample width of 0.5 $\mathrm{cm}$ and the highest acoustic impedance was 1,83 dyne.s/ $\mathrm{cm}^{3}$ at the frequency of $1000 \mathrm{~Hz}$ for the fiber of length $1 \mathrm{~cm}$, thus wood fibers panel is potential to be used as sound absorbing material. The acoustic impedance generally has a liniear relationship with the sound absorption coefficient at frequency $1000 \mathrm{~Hz}$ with $R^{2}=0,9489$.

Key words: sound absorption coefficient, acoustic impedance and red Meranti wood fibers, tube method 


\section{PENDAHULUAN}

Kualitas penyerapan bunyi oleh bahan bangunan idealnya menggunakan material yang dapat mengabsorbsi bunyi sehingga mengurangi kebisingan. Kebisingan adalah penyelubungan sumber bunyi oleh pantulan yang berlebihan sehingga vokal bunyi tersebut tidak terdengar jelas. Penyelubungan terjadi di dalam ruang dengan rancangan akustik yang kurang memadai misalnya penggunaan material akustik dengan koefisien absorbsi bunyi yang rendah. Kebisingan dapat dihasilkan oleh pengeras suara, kendaraan, peralatan yang dimekanisasi serta alat-alat rumah tangga seperti vacum cleaner, mesin pencuci piring, penghancur sampah dan televisi dengan frekuensi bunyi yang berbedabeda (Doelle, 1990).

Akibat dari kebisingan tersebut dapat berdampak negatif kepada kesehatan manusia, gangguan psikologis dan gangguan komunikasi. Untuk mengatasi hal tersebut dapat digunakan material akustik yaitu serat kayu Meranti Merah (Shorea Pinanga) sebagai bahan penyerap kebisingan. Serat kayu Meranti Merah dapat dibuat sebagai panel akustik dengan memvariasikan panjang serat dan lebar lembaran serat, dan serat tersebut dapat diperoleh dari pengataman kayu.

Material akustik adalah material yang dapat mengabsorbsi gelombang bunyi datang dengan kemampuan daya serap yang berbeda-beda. Kemampuan suatu material akustik menyerap bunyi dicirikan oleh koefisien absorbsi bunyi. Koefisien absorbsi bunyi adalah tingkat penyerapan gelombang bunyi oleh material akustik. Koefisien absorbsi bunyi ditentukan oleh ukuran serat, lubang, porositas dan rongga. Koefisien absorbsi bunyi tinggi biasanya dimiliki oleh material yang tidak keras namun tegar. Syarat material akustik untuk mempunyai nilai impedansi akustik yang baik yaitu memiliki koefisien absorbsi bunyi yang tinggi (Samsudin, dkk., 2016).

Peneliti sebelumnya telah menggunakan material akustik dari serat ampas tebu (Suban, 2015), serat kenaf (Berardi dan Iannace, 2015), serat ijuk (Sikora dan Turkiewicz, 2010). Serat ampas tebu sudah digunakan untuk membuat panel akustik dengan variasi panjang serat. Dari penelitian tersebut ditemukan bahwa semakin pendek ukuran panjang serat, semakin tinggi nilai koefisien absorbsi bunyi. Nilai koefisien absorbsi bunyi dengan matriks gipsum serat ampas tebu berukuran $10 \mathrm{~mm}$, lebih tinggi daripada serat ampas tebu berukuran $30 \mathrm{~mm}$. Koefisien absorbsi bunyi masing-masing adalah 0,15 dan 0,08 pada frekuensi $2000 \mathrm{~Hz}$. Dengan demikian, koefisien absorbsi bunyi masing-masing bahan relatif rendah. Hal ini kemungkinan disebabkan oleh matriks yang digunakan yaitu berupa gipsum .

Ukuran panjang serat mempengaruhi nilai koefisien absorbsi bunyi. Semakin pendek ukuran panjang serat, maka semakin tinggi nilai koefisien absorbsi bunyi. Misalnya koefisien absorbsi bunyi serat kenaf dengan panjang serat $4 \mathrm{~cm}$ lebih tinggi daripada 6 $\mathrm{cm}$. Koefisien absorbsi bunyi masing-masing adalah 0,59 dan 0,45 pada frekuensi 1000 Hz. Dengan demikian koefisien absorbsi bunyi masing-masing bahan relatif rendah (Berardi dan Iannace, 2015).

Ukuran diameter mempengaruhi nilai koefisien absorbsi bunyi. Semakin kecil ukuran diameter serat maka semakin tinggi nilai koefisien absorbsi bunyi. Nilai koefisien absorbsi bunyi serat ijuk berdiameter $30 \mathrm{~mm}$ lebih tinggi dari pada yang berdiameter 40 $\mathrm{mm}$. Koefisien absorbsi bunyi masing-masing adalah 0,78 dan 0,69 pada frekuensi 4000 Hz. Dengan demikian, koefisien absorbsi bunyi masing-masing bahan masih relatif 
rendah. Hal ini kemungkinan disebabkan oleh matriks yang digunakan berupa resin. Akibat menggunakan resin adalah gelombang bunyi lebih sulit untuk diserap (Sikora dan Turkiewicz, 2010).

Tujuan dari penelitian ini yaitu menganalisis pengaruh ukuran serat kayu Meranti Merah terhadap koefisien absorbsi bunyi dan impedansi akustik. Penelitian ini bermanfaat untuk mengurangi kebisingan dan mendaur ulang limbah serat kayu Meranti Merah sebagai material penyerap bunyi yang bernilai ekonomi. Perbandingan amplitudo tekanan ini dinamakan rasio gelombang tegak (Standing Wave Ratio). Secara matematis nilai rasio gelombang tegak dapat dinyatakan pada Persamaan 1 (Beranek, 1949).

$$
S W R=\frac{(A+B)}{(A-B)}
$$

Dengan $(A+B)$ yaitu amplitudo tekanan maksimum, $(A-B)$ yaitu amplitudo tekanan minimum dan $S W R$ yaitu rasio gelombang tegak. Koefisien absorbsi bunyi $(\alpha)$ dapat ditentukan dari Persamaan 2.

$$
\alpha=1-\left(\frac{S W R-1}{S W R+1}\right)^{2}
$$

Impedansi akustik dapat ditentukan dengan menggunakan persamaan 3 .

$$
Z_{s}=\operatorname{coth}\left(\psi_{1}+i \psi_{2}\right) \rho c
$$

Dengan $Z_{s}$ adalah impedansi akustik (dyne.s $/ \mathrm{cm}^{5}$ ), $\rho$ adalah kerapatan di udara, c adalah kecepatan bunyi di udara. Untuk dapat menentukan impedansi akustik terlebih dahulu harus ditentukan nilai $\psi_{1}$ dan $\psi_{2}$ dapat dinyatakan pada persamaan 4 dan Persamaan 5 (Beranek, 1949).

$$
\begin{aligned}
& \psi_{1}=\operatorname{coth}^{-1}\left(\log _{10}(S W R / 20)\right) \\
& \psi_{2}=\pi\left(\frac{1}{2}-\frac{d_{1}}{d_{n}}\right)
\end{aligned}
$$

$\psi_{1}, \psi_{2}$ adalah bilangan kompleks, $d_{1}$ yaitu jarak amplitudo minimum pertama dari sampel $(\mathrm{cm})$ dan $d_{2}$ adalah jarak amplitudo minimum kedua dari sampel $(\mathrm{cm})$

\section{METODE PENELITIAN}

\subsection{Pembuatan serat kayu Meranti merah ( Banio)}

Material komposit dibuat dari lembaran serat dengan panjang yang konstan yaitu $2 \mathrm{~cm}$ dan dengan lebar lembaran serat yang divariasikan. Lebar lembaran serat yang divariasikan adalah $0,5 \mathrm{~cm}, 1 \mathrm{~cm}, 1,5 \mathrm{~cm}$ dan $2 \mathrm{~cm}$. Sampel selanjutnya menggunakan lebar lembaran serat yang konstan yaitu $1 \mathrm{~cm}$ dan panjang yang divariasikan. Panjang serat yang divariasikan yaitu $1 \mathrm{~cm}, 2 \mathrm{~cm}, 3 \mathrm{~cm}$ dan $4 \mathrm{~cm}$ seperti diperlihatkan pada Lampiran A. Pembuatan sampel dilakukan dengan mencampurkan $10 \mathrm{~g}$ serat kayu Meranti Merah dengan 9,5 g lem PVC ke lumpang dan diaduk sampai merata. Serat lebih banyak dari pada lem supaya menghasilkan komposit yang kuat (Gibson,1994). Setelah merata, campuran serat dan lem dimasukkan ke dalam cetakan sampel dan dipadatkan menggunakan dongkrak hidrolik. Sebelum sampel dimasukkan, cetakan diolesi dengan lilin agar sampel mudah dilepas dari cetakan. Setelah ditekan sampel didiamkan dalam cetakan selama dua hari sampai mengering. Setelah lem kering dan merekat dengan baik sampel dilepaskan dari cetakan. 


\subsection{Pengujian menggunakan Tabung Impedansi}

Pengujian akustik untuk mengetahui kemampuan serat kayu Meranti Merah dalam menyerap bunyi, dilakukan dengan menggunakan tabung impedansi. Tabung impedansi dilengkapi dengan beberapa alat antara lain: mikrofon, amplifier, catu daya, osiloskop, sinyal generator, loudspeaker, skala dan sampel seperti diperlihatkan pada Gambar 1.

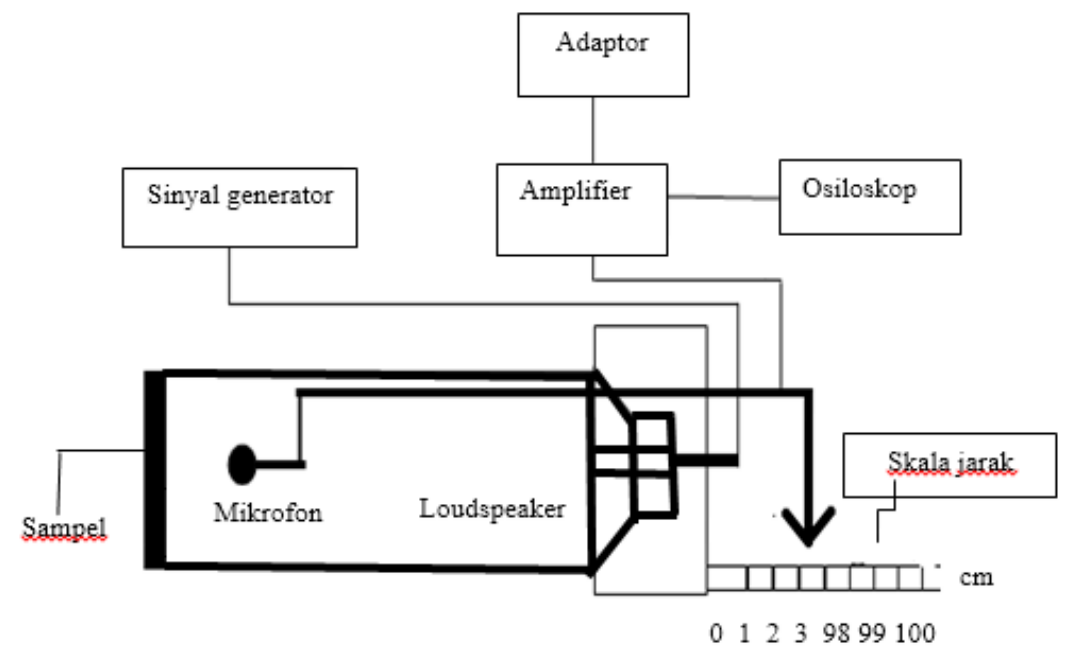

Gambar 1 Skema rangkaian tabung impedansi

Loudspeaker dihubungkan dengan generator sebagai penghasil bunyi. Diletakan ujung tabung loudspeaker dan ujung tabung yang lainnya adalah sampel. Mikrofon diletakkan ditengah-tengah diameter tabung ke arah sampel material akustik. Mikrofon diletakkan diujung sebuah kawat sehingga dapat digeser untuk menentukan amplitudo tekanan maksimum dan amplitudo tekanan minimum.

Mikrofon diperkuat dengan amplifier dan dihubungkan ke osiloskop seterusnya dilakukan pengukuran gelombang. Gelombang yang diukur adalah amplitudo tekanan maksimum dan amplitudo tekanan minimum serta jarak amplitudo minimum pertama $\left(d_{1}\right)$ dan jarak dari amplitudo minimum kedua $\left(d_{2}\right)$ dari sampel. Frekuensi yang digunakan dalam penelitian ini adalah frekuensi yaitu $500 \mathrm{~Hz}, 1000 \mathrm{~Hz}, 1500 \mathrm{~Hz}, 2000 \mathrm{~Hz}$ dan $2500 \mathrm{~Hz}$ (Doelle, 1986).

\section{HASIL DAN DISKUSI}

\subsection{Analisis Koefisien Absorbsi Bunyi Terhadap Frekuensi}

Karakteristik kemampuan absorbsi bunyi serat kayu Meranti Merah memiliki pola yang sama untuk setiap lebar lembaran serat. Nilai koefisien absorbsi bunyi tertinggi yaitu $0,95 \pm 0,05$ pada frekuensi $1000 \mathrm{~Hz}$ pada ukuran lebar lembaran serat yang paling kecil yaitu $0,5 \mathrm{~cm}$. Hal ini dikarenakan lebar lembaran serat yang lebih kecil,memiliki sambungan antar muka (interface) antara filler dengan matriks yang paling banyak dari pada ukuran yang lain. Banyaknya jumlah interface mengakibatkan terjadinya reduksi energi gelombang bunyi yang besar, sehingga nilai koefisien absorbsi bunyi tinggi seperti diperlihatkan pada Gambar 2.

Yuliantika dan Elvaswer

DOI: $10.25077 /$ jif.10.1.28-37.201831 


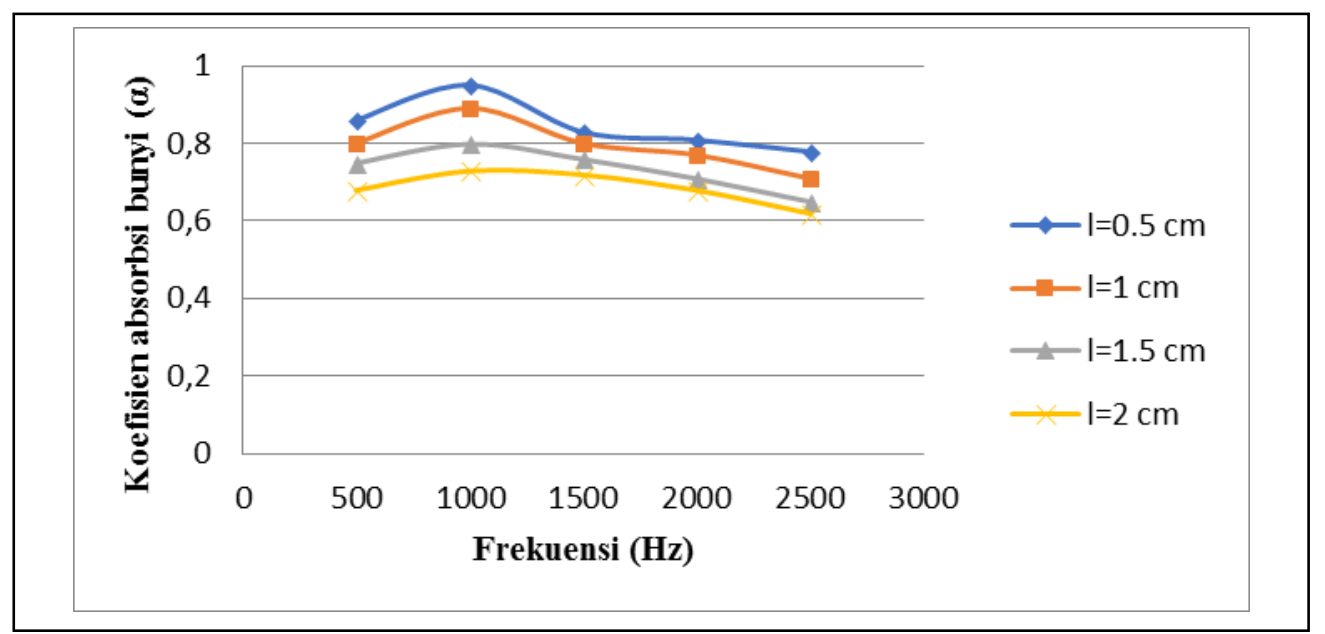

Gambar 2 Hubungan koefisien absorbsi bunyi $(\alpha)$ terhadap frekuensi untuk empat variasi lebar lembaran serat dengan panjang serat konstan $(2 \mathrm{~cm})$

Koefisien absorbsi bunyi paling rendah yaitu 0,62 $\pm 0,04$ pada frekuensi $2500 \mathrm{~Hz}$ pada lebar lembaran serat $2 \mathrm{~cm}$. Hal ini dikarenakan lebar lembaran serat yang paling besar memiliki jumlah interface yang paling sedikit dari pada ukuran yang lainnya. Sedikitnya jumlah interface mengakibatkan reduksi energi gelombang bunyi kecil, sehingga nilai koefisien absorbsi bunyi paling rendah.

Nilai koefisien absorbsi bunyi maksimum pada frekuensi $1000 \mathrm{~Hz}$. Hal ini dikarenakan frekuensi efektif untuk menyerap bunyi pada panel kayu adalah pada $1000 \mathrm{~Hz}$ (Doelle, 1990). Hal ini dikarenakan pada frekuensi $1000 \mathrm{~Hz}$ terjadinya penyerapan energi gelombang bunyi yang tinggi sehingga amplitudo gelombang pantul kecil, kecilnya amplitudo gelombang pantul mengakibatkan nilai koefisien absorbsi bunyi tinggi.

Nilai koefisien absorbsi bunyi paling tinggi untuk panjang serat $1 \mathrm{~cm}$ yaitu $0,91 \pm 0,03$ pada frekuensi $1000 \mathrm{~Hz}$. Hal ini dikarenakan komposit antara serat kayu Meranti Merah dengan matriks dapat membantu penyerapan bunyi. Interface yang saling berhubungan antara serat dengan matriks dapat meningkatkan penyerapan bunyi. Interface antara filler dan matriks kemungkinan menghasilkan interface dengan jumlah yang besar jika luas lembaran serat kecil. Ketika gelombang bunyi datang masuk kedalam sampel dengan ukuran panjang $1 \mathrm{~cm}$, gelombang bunyi diserap, kemudian bunyi diteruskan melewati interface. Ketika gelombang bunyi memasuki interface dengan jumlah yang banyak mengakibatkan gelombang bunyi melemah karena terjadinya penyerapan bunyi yang cukup tinggi. Melemahnya bunyi tersebut mengakibatkan amplitudo gelombang pantulnya kecil, sehingga bunyi yang dipantulkan melemah, mengakibatkan nilai koefisen absorbsi bunyi paling tinggi, seperti diperlihatkan pada Gambar 3

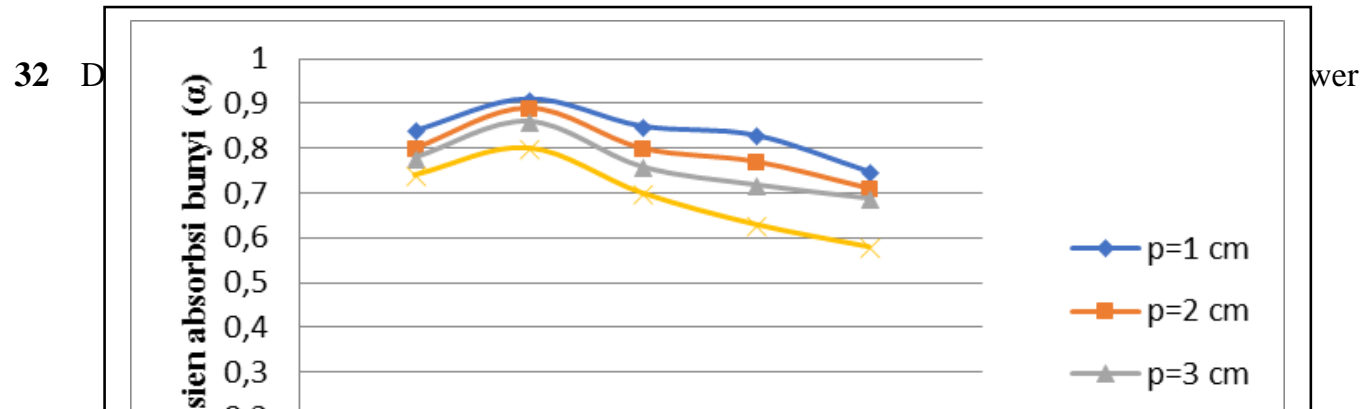


Gambar 3 Hubungan koefisien absorbsi bunyi $(\alpha)$ terhadap frekuensi untuk empat variasi panjang serat dengan lebar lembaran serat konstan $1 \mathrm{~cm}$

Koefisien absorbsi paling rendah yaitu $0,58 \pm 0,02$ pada frekuensi $2500 \mathrm{~Hz}$ dimiliki oleh sampel serat kayu Meranti Merah dengan panjang serat $4 \mathrm{~cm}$.Hal ini dikarenakan sampel memiliki porositas sedikit, sehingga mengalami resonansi yang kecil didalam pori (Berardi dan Iannace, 2015),terjadinya resonansi yang kecil mengakibatkan reduksi bunyi sedikit,sedikitnya reduksi bunyi mengakibatkan gelombang bunyi lebih banyak dipantulkan dari pada diserap,banyaknya gelombang bunyi dipantulkan mengakibatkan amplitudo gelombang pantul besar, besarnya amplitudo gelombang pantul mengakibatkan nilai koefisien absorbsi bunyi rendah.

Koefisien absorbsi bunyi pada serat kayu Meranti Merah meningkat pada frekuensi 1000 $\mathrm{Hz}$. Hal ini dikarenakan pada frekuensi $(1000 \mathrm{~Hz})$ akan terjadinya penyerapan gelombang bunyi yang besar ketika melewati sampel, berbeda dengan frekuensi tinggi (>1000 Hz) gelombang bunyi akan lebih banyak menyebar (dipantulkan dan ditransmisikan) (Lee dan Chen,2001) . Ketika terjadi penyerapan yang besar, maka mengakibatkan amplitudo gelombang pantulnya kecil, kecilnya amplitudo gelombang pantul mengakibatkan nilai koefisien absorbsi bunyi tinggi.

\subsection{Analisis Impedansi Akustik (Z) Terhadap Frekuensi}

Gambar 4 dan Gambar 5 memperlihatkan hubungan nilai impedansi akustik serat kayu Meranti Merah terhadap frekuensi. Nilai impedansi akustik paling tinggi yaitu 1,79 pada frekuensi $1000 \mathrm{~Hz}$ dengan lebar lembaran serat paling kecil yaitu 0,5 cm. Hal ini dikarenakan ukuran tersebut memiliki interface paling banyak, banyaknya interface mengakibatkan bunyi diserap lebih banyak dari pada yang dipantulkan.Banyaknya bunyi yang diserap sehingga nilai koefisien absorbsi bunyi tinggi, tingginya nilai koefisien absorbsi bunyi maka nilai impedansi akustik tinggi. 


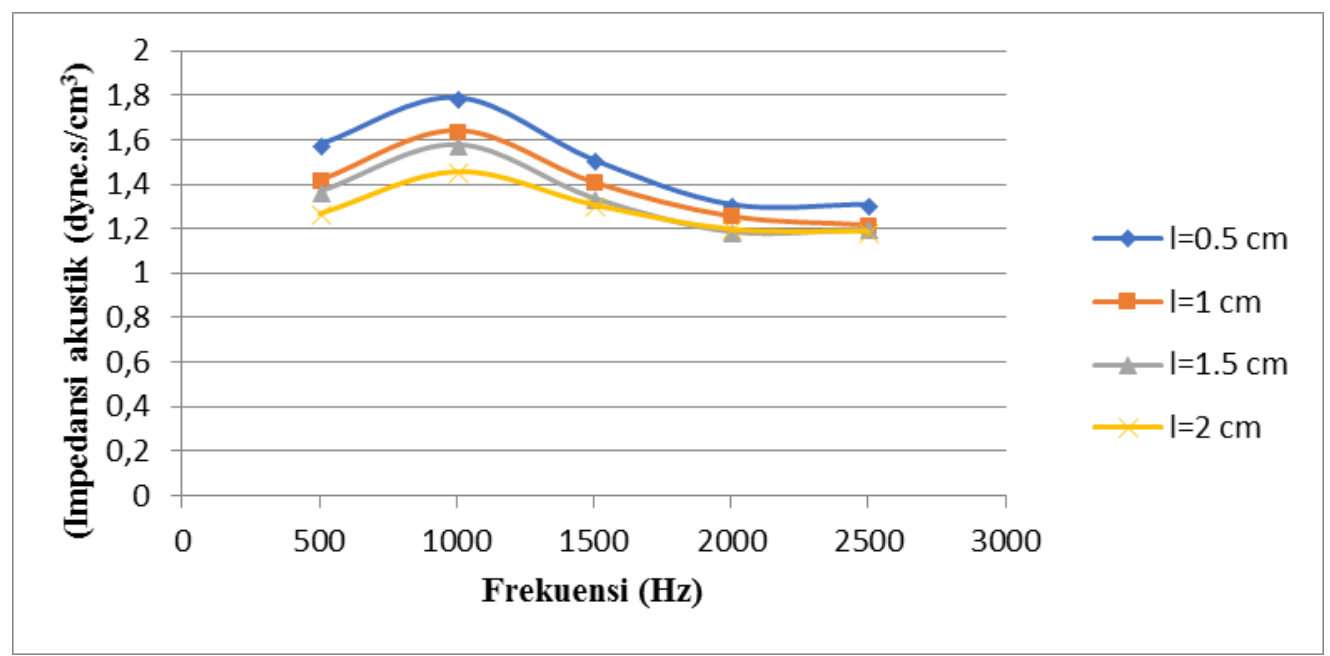

Gambar 4 Hubungan impedansi akustik (Z) terhadap frekuensi untuk empat variasi lebar lembaran serat dengan panjang serat konstan $2 \mathrm{~cm}$

Nilai impedansi akustik paling rendah yaitu 1,19 pada frekuensi $2500 \mathrm{~Hz}$ pada ukuran lebar lembaran serat $2 \mathrm{~cm}$. Hal ini disebabkan karena pada ukuran serat yang paling besar terjadi penyerapan bunyi yang paling rendah, sehingga gelombang bunyi yang dipantulkan lebih besar, besarnya bunyi yang dipantulkan sehingga nilai koefisien absorbsi bunyi rendah, rendahnya nilai koefisien absorbsi bunyi maka nilai impedansi akustik rendah.

Nilai impedansi akustik meningkat pada frekuensi $1000 \mathrm{~Hz}$, hal ini dikarenakan terjadinya penyerapan bunyi yang besar pada frekuensi $1000 \mathrm{~Hz}$. Penyerapan bunyi yang besar mengakibatkan gelombang bunyi yang dipantulkan sedikit, sedikitnya gelombang bunyi yang dipantulkan, mengakibatkan nilai koefisien absorbsi bunyi rendah, sehingga nilai impedansi akustik meningkat.

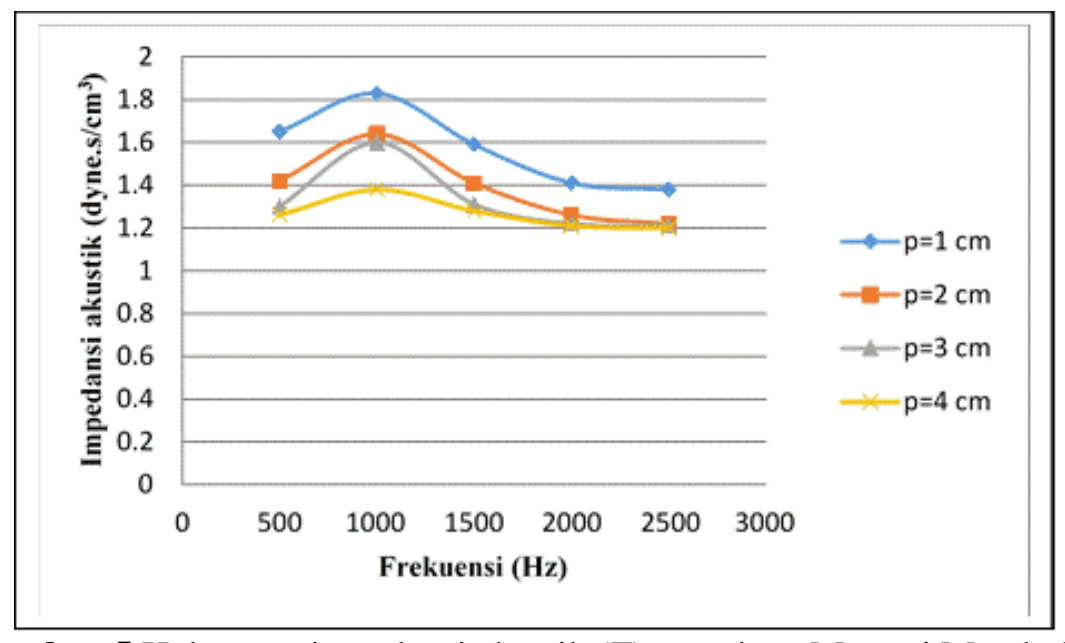

Gambar 5 Hubungan impedansi akustik (Z) serat kayuMeranti Merah dan frekuensi untuk empat variasi panjang dengan lebar lembaran

serat konstan $1 \mathrm{~cm}$

Nilai impedansi akustik paling tinggi yaitu 1,83 pada frekuensi $1000 \mathrm{~Hz}$ pada panjang serat $1 \mathrm{~cm}$ (Gambar 5). Hal ini dikarenakan sampel dengan ukuran terpendek terjadinya 
penyerapan bunyi yang besar, sehingga yang dipantulkan sedikit, sedikitnya bunyi yang dipantulkan, maka koefisien absorbsi bunyi tinggi, sehingga nilai impedansi akustik tinggi.

Nilai impedansi akustik paling rendah yaitu 1,20 pada frekuensi $2500 \mathrm{~Hz}$ pada panjang serat $4 \mathrm{~cm}$. Hal ini disebabkan serat dengan ukuran yang kecil memiliki jumlah pori-pori yang sedikit,sehingga bunyi yang diserap sedikit, dan bunyi yang dipantulkan besar. Besarnya gelombang bunyi yang dipantulkan, maka nilai impedansi akustiknya rendah.

Nilai impedansi akustik serat kayu Meranti Merah meningkat pada frekuensi $1000 \mathrm{~Hz}$. Hal ini dikarenakan pada frekuensi rendah $(1000 \mathrm{~Hz})$ akan terjadinya penyerapan gelombang bunyi yang besar, berbeda dengan frekuensi tinggi (> $1000 \mathrm{~Hz}$ ) gelombang bunyi akan menyebar (dipantulkan dan ditransmisikan) (Lee dan Chen, 2001). Ketika terjadi penyerapan yang besar, maka energi gelombang bunyi yang dipantulkan sedikit, sedikitnya energi gelombang bunyi yang dipantulkan mengakibatkan nilai koefisien absorbsi bunyi tinggi, sehingga nilai impedansi akustik tinggi.

\section{Hubungan Koefisien Absorbsi Bunyi Terhadap Impedansi Akustik}

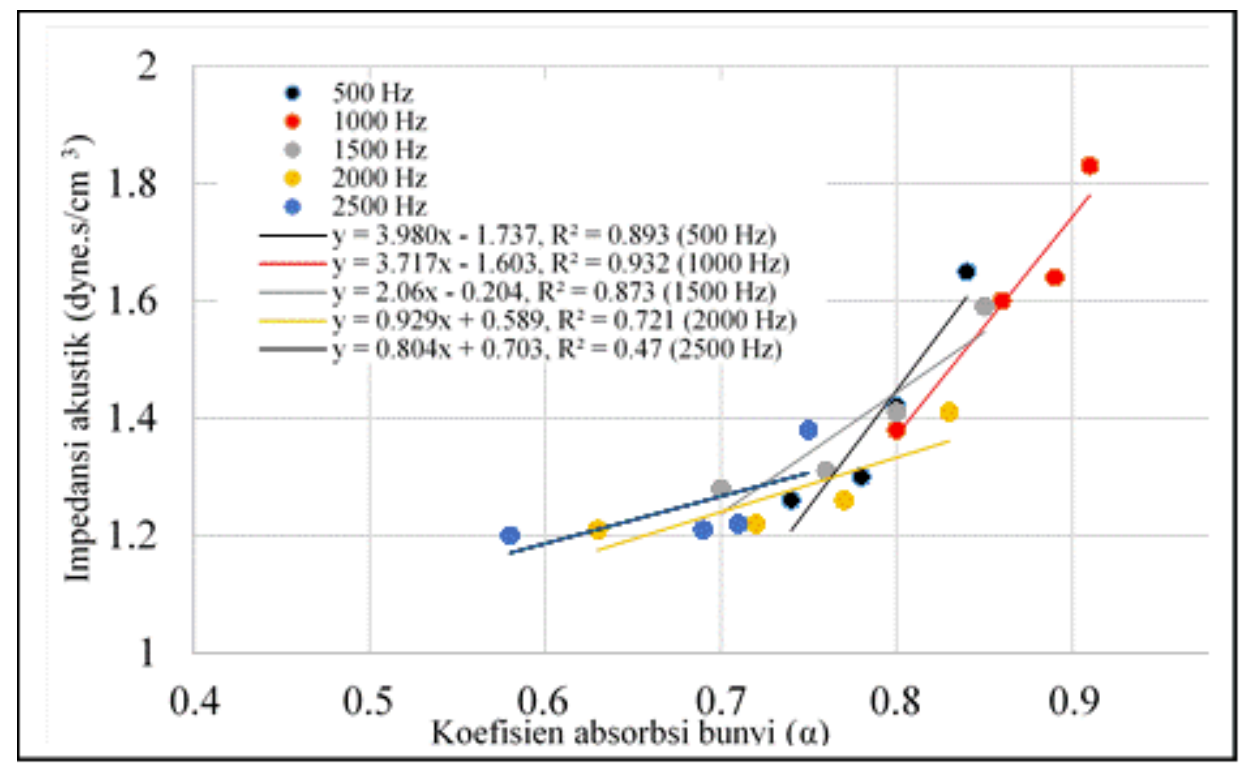

Gambar 6 Hubungan impedansi akustik (Z) serat kayu Meranti Merah dan koefisien absorbsi bunyi untuk empat variasi panjang serat dengan lebar lembaran serat konstan $1 \mathrm{~cm}$

Gambar 6 memperlihatkan korelasi antara nilai koefisien absorbsi bunyi dan impedansi akustik untuk empat variasi panjang serat dengan lebar lembaran serat konstan $1 \mathrm{~cm}$. Nilai korelasi antara koefisien absorbsi bunyi dan impedansi akustik lebih kecil pada frekuensi $2000 \mathrm{~Hz}$ hingga $2500 \mathrm{~Hz}$ dari pada frekuensi $500 \mathrm{~Hz}, 1000 \mathrm{~Hz}$ dan $1500 \mathrm{~Hz}$. Hal ini disebabkan karena nilai koefisien absorbsi bunyi dan impedansi akustik untuk frekuensi $2000 \mathrm{~Hz}$ hingga $2500 \mathrm{~Hz}$ lebih rendah dari pada frekuensi $500 \mathrm{~Hz}, 1000 \mathrm{~Hz}$ dan $1500 \mathrm{~Hz}$. 


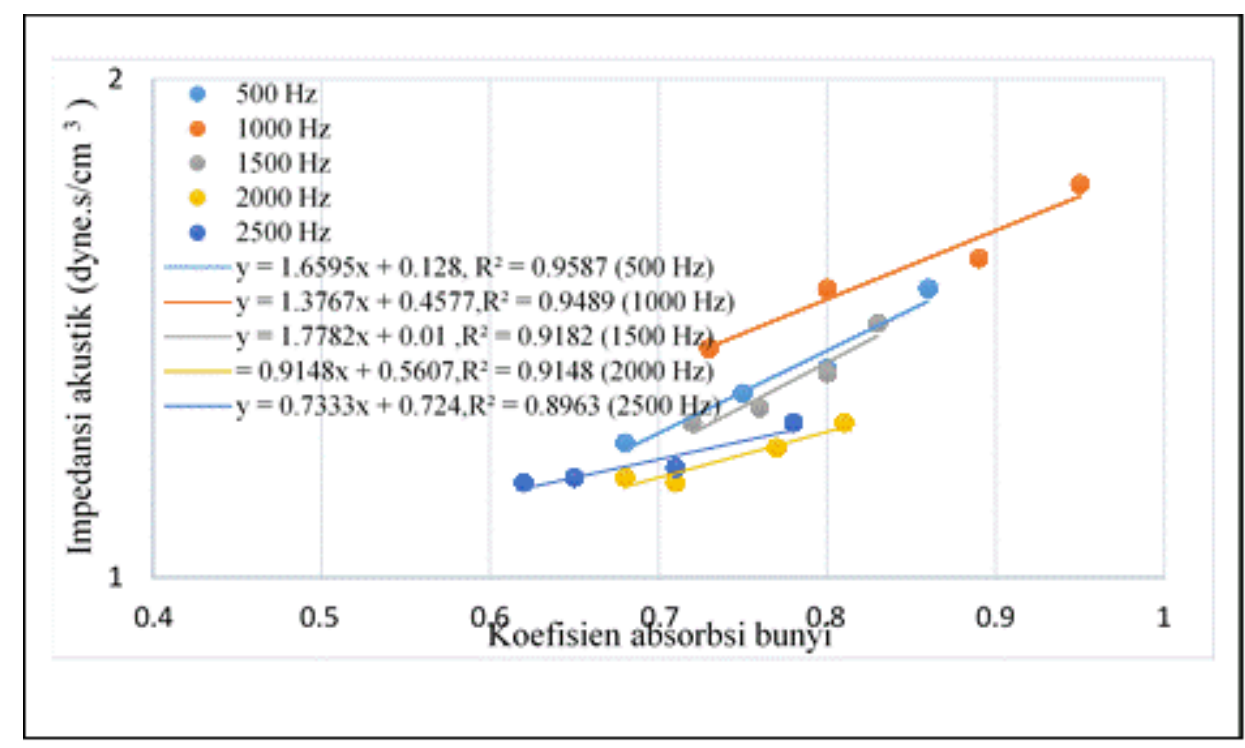

Gambar 7 Hubungan impedansi akustik (Z) serat kayu Meranti Merah dan koefisien absorbsi bunyi untuk empat variasi lebar lembaran serat dengan panjang serat konstan $1 \mathrm{~cm}$

Gambar 7 memperlihatkan korelasi antara koefisien absorbsi bunyi dan impedansi akustik untuk empat variasi lebar lembaran serat dengan panjang serat konstan $1 \mathrm{~cm}$. Korelasi antara koefisien absorbsi bunyi dan impedansi akustik lebih tinggi dari pada Gambar 6. Nilai korelasinya di atas 0,8 , hal ini dapat dikatakan bahwa nilai korelasi antara koefisien absorbsi bunyi dan impedansi akustik sangat kuat. Nilai korelasinya menurun pada frekuensi $2500 \mathrm{~Hz}$ dari pada frekuensi $500 \mathrm{~Hz}, 1000 \mathrm{~Hz}, 1500 \mathrm{~Hz}$ dan $2000 \mathrm{~Hz}$, hal ini dikarenakan nilai koefisien absorbsi bunyi dan impedansi akustik pada frekuensi $2500 \mathrm{~Hz}$ paling rendah daripada frekuensi $500 \mathrm{~Hz}, 1000 \mathrm{~Hz}, 1500 \mathrm{~Hz}$ dan $2000 \mathrm{~Hz}$. Dari ulasan diatas dapat disimpulkan bahwa semakin tinggi nilai koefisien absorbsi bunyi maka semakin tinggi nilai impedansi akustik.

\section{KESIMPULAN}

Berdasarkan penelitian yang telah dilakukan dapat disimpulkan bahwa:

Serat kayu Meranti Merah untuk semua lebar lembaran serat dan panjang serat pada semua frekuensi dapat digunakan sebagai bahan penyerap bunyi, karena berdasarkan ISO 11654, nilai koefisien absorbsi bunyi besar dari 0,6 berpotensial sebagai bahan penyerap bunyi. Penambahan panjang serat dan lebar lembaran serat mengakibatkan nilai koefisien absorbsi bunyi rendah. Sehingga mempertegas penelitian sebelumnya bahwa pengaruh ukuran panjang serat mempengaruhi nilai koefisien absorbsi bunyi. Nilai impedansi akustik secara umum memiliki hubungan yang kuat dengan koefisien absorbsi bunyi dengan nilai $\mathrm{R}^{2}=0,94$ pada frekuensi $1000 \mathrm{~Hz}$. 


\section{DAFTAR PUSTAKA}

1. Doelle, E., 1990, Akustik Lingkungan, (diterjemahkan oleh Lea Prasetio), Erlangga, Jakarta.

2. Samsudin, E.M., Ismail, L.H. dan Kadir, A.A., 2016, A Review On Physical Factors Influencing Absorption Performance of Fibrous Sound Absorption Material From Natural Fibers, ARPN Journal of Engineering And Applied Sciences, Vol.11, No. 6, Hal. 3703-3711.

3. Suban,S.L.dan Farid,S., 2015, Pengaruh Panjang Serat Terhadap Nilai Koefisien Absorbsi Suara dan Sifat Mekanik Komposit Serat Ampas Tebu Dengan Matriks Gipsum, Jurnal Teknik ITS, Vol. 4, No.1.

4. Berardi, U dan Iannace, G., 2015, Acoustic Characterization Of Natural Fibers For Sound Absorption Applications, Journal Building and Environtment, Vol.94, Hal.840852.

5. Sikora,J.dan Turkiewicz, J., 2010, Sound Absorption Coefficient Of Granular Materials, Journal Menchanics And Control, Vol.29, No.3, Hal. 149-157.

6. Beranek, L., 1949, Acoustic Measurement, John Wiley \& Sons, Inc., New York.

7. Gibson, R.F., 1994, Principles Of Composites Material Mechanics, MC Graw -Hill, Singapura.

8. Lee,F.C. dan Chen, W.H., 2001, Acoustic Transmission Analysis Off Multilayer Absorbers, Journal Sound Vibration, Vol.8, No.4, Hal. 621-634 